\title{
Postfire Plant Establishment: THE EFFECTS OF ENVIRONMENT, Prefire Vegetation, Fire Severity, AND LANDSCAPE POSITION IN Grand Teton National Park
}

\author{
KATHLEEN M. DOYLE $\downarrow$ DENNIS H. KNIGHT \\ DEPARTMENT OF BOTANY $\uparrow$ UNIVERSITY OF WYOMING \\ LARAMIE
}

\section{$\uparrow \quad$ INTRODUCTION}

Observations in the Rocky Mountains and elsewhere indicate that vegetation patterns that develop soon after forest fires vary considerably. This variability is evident even on sites that have similar environmental conditions. The causes of this heterogeneity are not well known, but it is now recognized that the conditions present soon after fire, and the plants that become established initially, influence the nature of the vegetation over the next 100-200 years or more (Glenn-Lewin et al. 1992).

Our research investigates the causes of the variability in vegetation establishment following fire in Grand Teton National Park and the Bridger Teton National Forest. The specific objectives of our research are as follows: 1) determine the range of variability in the patterns of early postfire succession; 2) determine which environmental and historical variables are most important in controlling vegetation development following fire; 3) elucidate the importance of landscape position and betweenpatch interactions during early postfire succession; 4) develop a series of multivariate models that will predict the characteristics of early succession in different situations; and 5) project the most probable trajectories of each pioneer community type.
This research will contribute to our knowledge of Wyoming's vegetation in several important ways. First, our research promises to be a significant addition to ongoing fire ecology research in the Greater Yellowstone Area. The wide range of geologic, topographic and hydrologic conditions in the Teton region contrast with the more homogeneous subalpine plateaus of adjacent Yellowstone N.P. The ability to predict early successional vegetation patterns and long-term vegetation development following fire should be useful to land managers in the region who are striving to implement "ecosystem management". Moreover, the National Park Service and National Forest Service are continually evaluating the "natural (fire) regulation policy" and the need for prescribed burning. Second, our research will provide a better understanding of the factors that influence early successional vegetation patterns in the Rocky Mountains, and could serve as a model for investigating postfire vegetation in other heterogeneous landscapes. The influence of landscape patterns on the development of postfire vegetation mosaics has not been adequately considered. In addition, the effects of soil nutrient availability on early postfire vegetation in Rocky Mountain forests are poorly understood. Other 
researchers (e.g., Hoff 1957, Despain 1973, Wentworth 1981) have indicated that substrate and nutrient availability may influence the distribution of vegetation types.

\section{STUDY SITES AND METHODS}

Our study sites include six areas which have burned in the last 20 years. The six burned areas range in size from 400 ha to greater than 32,400 ha. The majority of the regions's major forest types and substrate types are represented within the burned areas. We have collected vegetation and environmental data from 81 burned stands (226 plots). Stands have been stratified across the landscape with respect to the range of variability in site factors (elevation, slope, aspect and substrate type), spatial variables (e.g., distance to unburned forest, proximity to ridgetop), burn severity, and prefire vegetation. Our vegetation data include: postfire tree seedling density, percent cover of all understory species, prefire tree species composition, and the composition of understory species in nearby unburned forests.

\section{PROGRESS REPORT}

Funds obtained from UW-NPS in 1995 were used to cover the cost for analyzing soil nutrients in 95 plots. Chemical and texture analyses of surface soils are being conducted for all 226 plots. Preliminary analysis from approximately $40 \%$ of our plots show considerable variability in almost all of the soil variables measured. For example, percent sand varied from 24 to $71 \%$, cation exchange capacity from 6 to 35 milliequivalents $/ 100 \mathrm{~g}$, and nitrate- $\mathrm{N}$ from 0.4 to $22.4 \mathrm{ppm}$.

\section{CONCLUSIONS}

Surface soil texture (\%sand, \%silt, \%clay) and soil nutrient availability data from recently burned stands indicate that a wide range in soil conditions is present on recently burned sites in Grand Teton National Park and in nearby Bridger Teton National Forest. These data suggest that soil conditions may contribute to the variability in early successional vegetation patterns that we have observed in the region. Ongoing analyses will examine soil-vegetation relationships further.

\section{LITERATURE CITED}

Despain, D.G. 1973. Vegetation in the Big Horn Mountains, Wyoming, in relation to substrate and climate. Ecology 43:329355 .

Glenn-Lewin, D.C., R.K. Peet and T.T. Veblen. 1992. Plant succession: theory and prediction. Chapman and Hall, New York.

Hoff, C.C. 1957. A comparison of soil, climate and biota of conifer and aspen communities in the central Rocky Mountains. American Midland Naturalist 58:115-140.

Wentworth, T.R. 1981. Vegetation on limestone and granite in the Mule Mountains, Arizona. Ecology. 62:469-482. 